\title{
PENERAPAN MODEL PEMBELAJARAN PROJECT BASED LEARNING UNTUK MENINGKATKAN AKTIVITAS DAN HASIL BELAJAR GAMBAR TEKNIK SISWA SMK NEGERI 1 PARIAMAN
}

\section{THE APPLICATION OF MODEL LEARNING PROJECT BASED LEARNING FOR INCREASE ACTIVITIES AND LEARNING OUTCOMES ENGINEERING DRAWING STUDENTS OF VOCATIONAL SCHOOL IPARIAMAN}

\author{
Yulira Emputri ${ }^{(1)}$, Ambiyar ${ }^{(2)}$, Arwizet $\mathrm{K}^{(3)}$ \\ (1),(2),(3) Jurusan Teknik Mesin, Fakultas Teknik, Universitas Negeri Padang \\ Kampus Air Tawar, Padang 25131, Indonesia \\ yulira_emputri@yahoo.co.id \\ ambiyar@ymail.com Arwizet@yahoo.com
}

\begin{abstract}
Abstrak
Keberhasilan suatu pembelajaran dapat dilihat dari perolehan nilai hasil belajar siswa. Perolehan nilai gambar teknik siswa kelas X TPM SMK Negeri 1 Pariaman semester genap tahun pelajaran 2015/2016 menunjukkan belum tercapainya keberhasilan pembelajaran tersebut. Hal ini karena pembelajaran didominasi oleh guru karena menerapkan model pembelajaran dengan metode ceramah, sehingga membatasi aktivitas belajar siswa mengakibatkan hasil belajar siswa juga rendah. Tujuan penelitian ini untuk meningkatkan aktivitas dan hasil belajar siswa kelas X TPM melalui penerapan model pembelajaran project based learning di SMK Negeri 1 Pariaman. Penelitian ini merupakan penelitian tindakan kelas dimana peneliti bertindak sebagai guru yang melakukan tindakan. Penelitian ini dilaksanakan pada bulan Februari-Maret 2017. Penelitian ini terdiri dari tiga siklus yang masing-masing terdiri dari dua kali pertemuan. Data dikumpulkan menggunakan lembar observasi untuk melihat perubahan aktivitas belajar siswa setiap siklusnya dan untuk pengukur data hasil belajar siswa digunakan lembaran tes.

Berdasarkan hasil pengamatan, rata-rata aktivitas siklus I adalah 60, 47\% dan pada siklus II adalah 70,055 siklus III adalah $80,16 \%$. Selain aktivitas belajar siswa, hasil belajar juga mengalami peningkatan ketuntasan klasikal. Pada siklus I ketuntasan klasikal adalah 55,00\% dengan 22 siswa tuntas dan pada siklus II adalah 70,00\% dengan 28 siswa tuntas pada siklus III $80.00 \%$ dengan 32 siswa tuntas. Dapat disimpulkan penggunaan model pembelajaran project based learning dapat meningkatkan aktivitas dan hasil belajar siswa pada mata pelajaran gambar teknik di kelas X TPM SMK Negeri 1 Pariaman.
\end{abstract}

Kata Kunci : Aktivitas, Hasil Belajar, Model Pembelajaran, Project Based Learning, Gambar Teknik.

\begin{abstract}
The success of a learning can be seen from the acquisition value of the activity and results of the learning of their students. Acquisition value of subjects engineering drawing Class $X$ SMK Negeri 1 Pariaman even-numbered year semester lesson 2015/2016 demonstrate the success of the learning achievement yet. This is because learning is still dominated by a teacher centered and still apply to conventional learning model with methods lectures, thus limiting the student's learning activities resulted in student learning outcomes is also low.
\end{abstract}


The purpose of this research was to improve the activity and results of student learning through the application of model learning project based learning at SMK Negeri 1 Pariaman. This research is a research action class where the teacher acts as a researcher who did the action. This research was carried out in February-March 2017. This research consists of three cycles in two meetings. The data collected using the observation sheet to see the change in student learning activities each cycle and for measuring student learning outcomes used data sheet tests. Based on the observations, the average activity cycle I was $60,47 \%$ and cycle II is 70.055 cycle III is $80.16 \%$. In addition to the learning activities of students, the results of the study also experienced an increase in ketuntasan classical. On cycle I ketuntasan classical is 55.00\% with 22 students comprehensively and in cycle II is $70.00 \%$ with 28 students and discharging cycle III $80.00 \%$ with 32 students completely. It can be concluded that the use of model learning project based learning can improve student learning outcomes and activities on subjects drawing techniques in class X TPM SMK Negeri 1 Pariaman.

Keywords: Activity, Learning Outcomes, Model Of The Learning Project Based Learning, Engineering Drawings.

\section{Pendahuluan}

Pendidikan merupakan suatu kebutuhan yang sangat penting dalam pembangunan dan kehidupan manusia. Sebagaimana yang dikemukakan dalam pembukaan UndangUndang Dasar 1945 bahwa, tujuan pembangunan nasional Indonesia untuk melindungi segenap bangsa Indonesia dan seluruh tumpah darah Indonesia dan memajukan kesejahteraan umum dan mencerdaskan kehidupan bangsa. Untuk mencapai tujuan pembangunan nasional tersebut dapat dilakukan melalui lembaga pendidikan dimulai dengan pendidikan dasar sampai perguruan tinggi formal maupun non formal melalui kegiatan pembelajaran (belajar mengajar). Proses belajar mengajar sebaiknya dilaksanakan dengan melibatkan mental siswa secara individu dengan maksimal, agar aktivitas siswa tidak sebatas mendengarkan, mencatat penjelasan dari guru dan membuat latihan seadanya dalam proses pembelajaran. Pada kegiatan pembelajaran demikian, guru cenderung hanya menuangkan ilmu pengetahuan kepada siswa tanpa adanya timbal balik dari siswa itu sendiri. Strategi pembelajaran ini dinamakan dengan strategi pembelajaran yang berpusat pada pendidik. Menurut Sudjana (2010:35) kelemahan strategi pembelajaran yang berpusat pada pendidik adalah: (1) mudah menimbulkan rasa bosan pada peserta didik, sehingga hal ini dapat mengurangi motivasi, perhatian, dan konsentrasi peserta didik terhadap kegiatan pembelajaran; (2) keberhasilan pembelajaran, dalam hal perubahan sikap dan perilaku peserta didik, relatif sulit untuk diukur karena yang diinformasikan kepada peserta didik pada umumnya lebih banyak menyentuh ranah kognisi; (3) kualitas pencapaian tujuan belajar yang telah ditetapkan adalah relatif rendah karena pendidik sering hanya mengejar target waktu untuk menghabiskan materi pembelajaran.. Bertitik tolak dari penjelasan di atas, maka seorang guru diharapkan memiliki kemampuan dalam memilih strategi yang tepat dalam melaksanakan proses pembelajaran di kelasnya, sehingga tujuan yang telah dituliskan dalam rencana pengajaran dapat tercapai. Berdasarkan penjelasan tersebut diketahui bahwa seorang guru dituntut untuk menguasai metode dan strategi dalam pembelajaran. Guru sebagai fasilitator dalam proses pembelajaran harus mampu melibatkan siswa secara aktif dalam proses pembelajaran. Tidak hanya memberikan penjelasan di depan kelas, tetapi mampu untuk mengajak siswa berpikir dan merespon pembelajaran yang dilaksanakan. Salah satu indikator keberhasilan proses belajar mengajar di sekolah adalah pencapaian hasil belajar siswa. 
Menurut Abu Ahmadi dan Widodo Supriyono (2013:78-93) terdapat 2 faktor yang mempengaruhi keberhasilan siswa dalam belajar, yaitu faktor internal dan faktor eksternal. Faktor internal dalam pembelajaran meliputi sebab yang bersifat fisik dan sebab-sebab karena rohani. Faktor eksternal meliputi faktor orang tua, keadaan ekonomi keluarga, faktor sekolah, faktor mass media dan lingkungan sosial. Lebih jauh lagi, salah satu fator eksternal yang mempengaruhi keberhasilan siswa dalam belajar pada faktor sekolah, yaitu metode mengajar guru.. Menurut Rusman (2012:201202) dalam model pembelajaran kooperatif, guru lebih berperan sebagai fasilitator yang berfungsi sebagai jembatan penghubung ke arah pemahaman yang lebih tinggi, dengan catatan siswa sendiri. Guru tidak hanya memberikan pengetahuan pada siswa, tetapi juga harus membangun pengetahuan dalam pikirannya. Siswa mempunyai kesempatan untuk mendapatkan pengalaman langsung dalam menerapkan ide- ide mereka, ini merupakan kesempatan bagi siswa untuk menemukan dan menerapkan ide-ide mereka sendiri.. Model pembelajaran project based learnig merupakan pendekatan, strategi atau metode pembelajaran yang berpusat pada siswa. Menurut Ridwan Abdullah Sani (2014:172) model pembelajaran project based learnig sebagai sebuah pembelajaran dengan aktifitas jangka waktu panjang yang melibatkan siswa merancang, membuat, dan menampilkan produk untuk mengatasi dunia nyata. (Thomas, dkk, 1999) dalam Wena (2014:144) berpendapat bahwa pembelajaran berbasis proyek merupakan model pembelajaran yang memberikan kesempatan kepada guru untuk mengelola pembelajaran di kelas dengan melibatkan siswa dalam kerja proyek. Berdasarkan pendapat tersebut dapat disimpulkan definisi model pembelajaran project based learning adalah suatu metode pembelajaran dengan pemberian tugas-tugas berupa proyek yang melibatkan siswa secara aktif yang bertujuan untuk meningkatkan daya pikir siswa. Hasil pengamatan dan keterangan yang diperoleh dari guru di SMK Negeri 1 Pariaman, hasil belajar gambar teknik siswa masih sangat rendah., sehingga untuk mencapai batas standar kelulusan untuk mata diklat gambar teknik belum bisa terwujudkan. Hal ini dapat diketahui dari rata-rata nilai rapor mata diklat gambar teknik kelas $\mathrm{X}$ Teknik Mesin di SMK Negeri 1 Pariaman. Rendahnya hasil belajar pada mata diklat gambar teknik diantaranya karena masih belum bervariasinya metode pembelajaran yang digunakan guru dalam kelas, guru cenderung menjelaskan pembelajaran dan memberikan latihan. Guru belum pernah memberikan tugas ke siswa untuk membuat gambar dalam bentuk produk. mengingat bahwa mata diklat gambar teknik ini merupakan mata diklat produktif yang proses belajar mengajar sepenuhnya dilaksanakan di dalam kelas, sehingga siswa cenderung merasa bosan dan tidak mengikuti proses dengan baik. Karena siswa SMK lebih cenderung praktek di workshop. Oleh karena itu diperlukan adanya penerapan metode pembelajaran yang bervariasi dan menuntut siswa untuk berperan aktif dalam proses pembelajaran. Mengembangkan potensi dan kemampuan yang dimiliki siswa serta dapat menemukan makna dari apa yang dipelajari. Upaya untuk meningkatkan aktifitas dan hasil belajar siswa. Model pembelajaran project based learning merupakan suatu variasi model pembelajaran yang relevan dilaksanakan di SMK karena model pembelajaran project based learning ini hakikatnya melibatkan siswa dalam penyelesaian projek atau tugas yang diberikan oleh guru dikelas. .Penerapan model pembelajaran project based learning diharapkan dapat meningkatkan aktifitas dan hasil belajar siswa pada mata diklat gambar teknik.

\section{Metode Penelitian}

Penelitian ini merupakan metode penelitian tindakan kelas classroom action research yang tujuannya untuk memperbaiku mutu praktik pembelajaran di kelas. Dalam 
pelaksanaan penelitian ini terdapat tiga siklus yang terdiri dari siklus satu, siklus dua, dan siklus tiga. Pada setiap siklus terdapat empat tahap dalam pelaksanaannya, yaitu perencanaan, tindakan, observasi dan refleksi. Penelitian ini dilaksanakan sebanyak tiga siklus selama 6 minggu, yang mana dalam 1 siklus terdiri atas 2 kali pertemuan tatap muka. Untuk kelancaran penelitian, diperlukan prosedur dalam penelitian yang berhubungan dengan masalah yang akan diteliti yaitu dalam bentuk persiapan penelitian. Prosedur penelitian adalah langkah-langkah yang digunakan untuk memperoleh data dari sumber yang diteliti mulai dari awal sampai akhir untuk disajikan dalam bentuk penelitian. Jalannya penelitian yang dilakukan sampai dengan penyusunan penelitian ini adalah melalui dua tahap yaitu:

\section{A. Tahap Persiapan}

Tahap ini merupakan usaha untuk mempersiapkan penelitian, dalam hal ini yang dipersiapkan antara lain:

1. Mengadakan koordinasi dengan guru yang mengajar mata diklat gambar teknik.

2. Menetapkan obyek penelitian yaitu siswa yang mengambil mata diklat gambar teknik semester Januari - Juni tahun pelajaran 2016 / 2017.

3. Membuat rencana skenario pembelajaran.

4. Menyusun silabus, RPP sistem penilaian, dan soal-soal evaluasi.

5. Merencanakan waktu untuk pelaksanaan tindakan.

6. Menyusun serangkaian tindakan kegiatan secara menyeluruh.

7. Menyiapkan teknik pemantauan pada setiap tahapan penelitian.

B. Tahap Pelaksanaan Penelitian

Direncanakan penelitian ini terdiri atas 3 siklus. Rencana umum tindakan meliputi pelaksanaan diskusi strategi pembelajaran serta menyusun rencana tindakan dalam siklus
I, siklus II, dan siklus III. Setiap siklus terdiri dari empat tahapan, dapat dilihat dalam gambar dibawah.

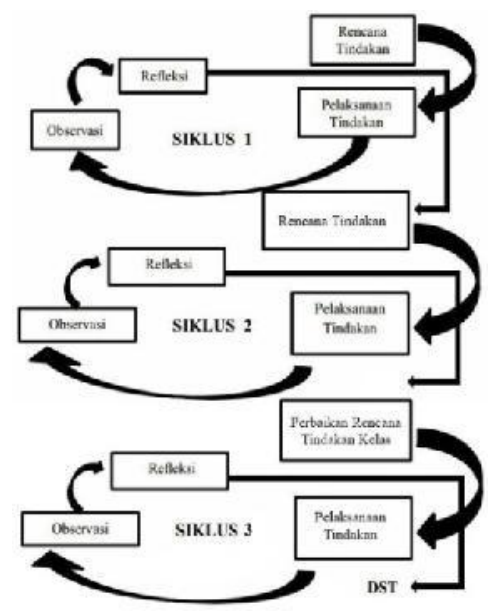

Gambar 1.Siklus Penelitian Tindakan Kelas (PTK). (Sunyono, 2009:24)

\section{Hasil dan Pembahasan}

A. Peningkatan Aktivitas Siswa pada Mata Pelajaran Gambar Teknik menggunakan Model Pembelajaran Project Based Learning.

Pelaksanaan pembelajaran siklus I didapatkan rata-rata aktivitas siswa dalam kategori cukup aktifyang kemudian pada siklus II menjadi kategori cukup aktif. Siklus III meningkat menjadi aktif. Dari siklus I ke siklus II, siswa terlihat belum terlihat perubahan dalam proses pembelajaran. Siklus III mulai terjadi peningkatan siswa dalam proses pembelajaran terlihat dari meningkatnya aktifitas belajar dan hasil belajar siswa. Aktifitas dan hasil belajar akan berpengaruh dengan model pembelajaran yang digunakan oleh guru. Seorang guru dituntut untuk dapat memilih model pembelajaran yang cocok dengan materi yang akan diberikan kepada siswa. Pada model pembelajaran project based learning, siswa lebih aktif dalam bertanya 
dan memahami materi karena siswa nanti akan diberikan tugas yang harus disiapkan. Siswa akan terpacu dalam menyelesaikan tugasnya. Hasil penelitian yang telah dilakukan, dapat disimpulkan bahwa penggunaan model pembelajaran project based learning mampu meningkatkan aktivitas siswa. Peningkatan aktivitas siswa dalam belajar ini dibuktikan dengan peningkatan keaktifan siswa dari siklus I ke siklus II dan ke III yang telah mencapai indikator keberhasilan tindakan yang ditentukan. Penelitian aktivitas yang dilakukan didapatkan hasil sebagai berikut:

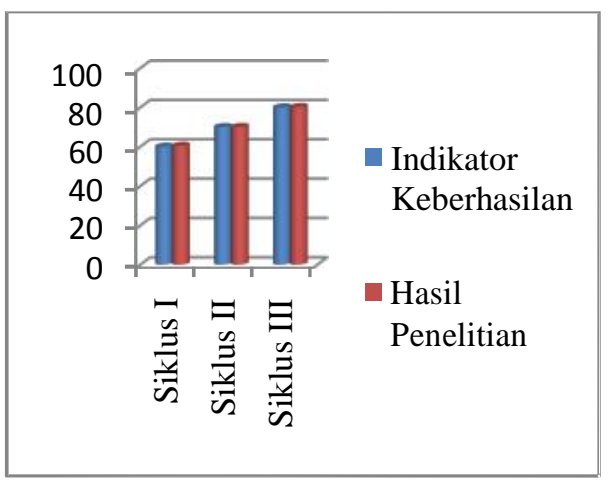

Gambar 2. Diagram Peningkatan Aktivitas Siswa

B. Peningkatan Hasil Belajar Siswa pada Mata Pelajaran Gambar Teknik menggunakan Model Pembelajaran Project Based Learning.

Data yang telah diperoleh berdasarkan hasil penelitian, diketahui bahwa terjadi peningkatan jumlah siswa yang memperoleh nilai mencapai KKM yaitu 75. Dari total 40 siswa, pada siklus I sebanyak 22 siswa dinyatakan tuntas dalam belajar dengan nilai mencapai KKM dan pada siklus II terjadi peningkatan siswa yang tuntas belajar menjadi 28 orang, pada siklus III siswa yang tuntas sebanyak 32 orang. Berdasarkan penelitian yang telah dilakukan, dapat disimpulkan bahwa penggunaan model pembelajaran project based learning mampu meningkatkan hasil belajar siswa. Sejalan dengan dengan hasil penelitian Bayu Permana 2015 bahwa penerapan model pembelajaran project based learning dapat meningkatkan hasil belajar siswa. Peningkatan hasil belajar ini, dibuktikan dengan peningkatan ketuntasan klasikal dari siklus I ke siklus II dan siklus III yang telah mencapai indikator keberhasilan tindakan yang ditentukan. Hasil penelitian ini dapat meningkatkan aktivitas belajar siswa kelas X TPM di SMK Negeri 1 Pariaman pada mata pelajaran Gambar Teknik.

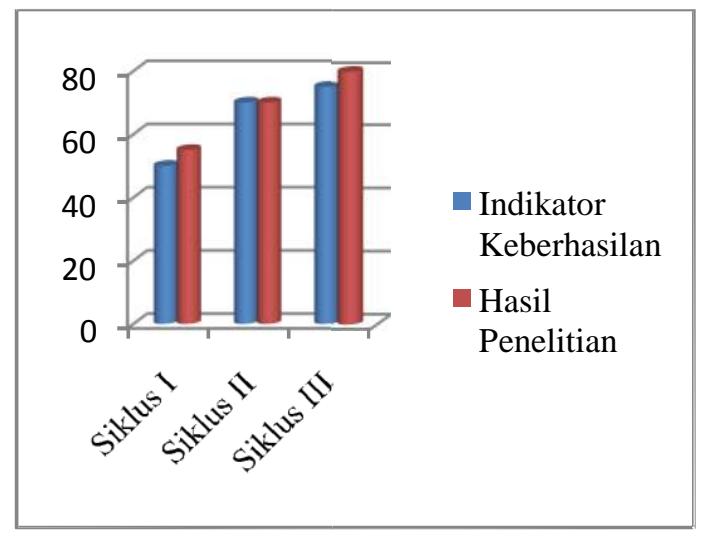

Gambar 3. Diagram Hasil Belajar Siswa

\section{Kesimpulan}

Berdasarkan hasil analisis data yang diperoleh dalam penelitian ini dapat dirumuskan kesimpulan yaitu:

A. Penerapan metode pembelajaran project based learning dapat meningkatkan aktivitas belajar gambar teknik di SMK N 1 Pariaman. Terlihat dari peningkatan aktivitas belajar antara siklus I siklus II dan siklus III. Siklus I aktivitas belajar mencapai $60.47 \%$ dan pada siklus II aktivitas belajar mencapai $70.05 \%$ siklus III $80.16 \%$. Sementara pada hasil belajar siswa yang telah dilakukan. Pada siklus I ketuntasan klasikal mencapai 55\% dan pada siklus II ketuntasan klasikal mencapai $70.00 \%$ siklus III $80.00 \%$.

B. Penerapan metode pembelajaran project based learning dapat meningkatkan hasil 
belajar siswa. Hasil belajar dapat tercapai karena pada penerapan metode pembelajaran ini siswa diarahkan untuk memahami materi melalui diskusi, tugas, memahami sumber belajar berupa bertanya dan menjawab pertanyaan. Siswa dituntut untuk aktif.

\section{Referensi}

Abu Ahmadi dan Widodo Supriyono. 2013. Psikologi Belajar. Jakarta: Rineka Cipta.

Made Wena. 2014. Strategi Pembelajaran Inovatif Kontemporer : Suatu Tinjauan Konseptual Operasional. Jakarta : Bumi Aksara.

Ridwan Abdullah Sani. 2014. Pembelajaran Saintifik. Jakarta:Bumi Aksara.

Rusman. 2012. Model-model Pembelajaran: Mengembangkan

Profesionalime Guru. Jakarta:

Rajawali Pers.

Sudjana. 2010. Metode dan Teknik Pembelajaran Partisipatif.

Bandung: Falah Production

$\begin{array}{lr}\text { Sunyono.2009. Perancangan } & \text { PTK dan } \\ \text { Penulisan Karya } & \text { Ilmiah. } \\ \text { Unila:Bandar Lampung } & \end{array}$

